\title{
Research on Application of Color Design in Urban Community
}

\author{
Shu Zhang \\ School of Art and Design \\ Wuhan University of Science and Technology \\ Wuhan, China
}

\begin{abstract}
This paper introduces "community" according to changes of time, states the functional transformation of urban community and expression methods of color design in community. The value of color design in the construction of community culture is embodied through cases of Dulux in several art communities of China, in order to emphasize the importance and cultural transmission of color design in urban community.
\end{abstract}

Keywords-color design; urban community; community culture

\section{FUNCTIONAL TRANSFORMATION OF URBAN COMMUNITY}

The word community derives from Latin. In Xinhua Dictionary, "She" refers to place, date and area for sacrificial rites of land god in ancient times. "Qu" refers to region. The definition of community is the social life community constituted by correlative people in a certain region. "Community" is the regional social entity formed by people in politics, economy and culture. Since modern times, this word has been applied to the study of sociology by Germany. After World War I, "community" is widely used by American sociology circle. In the 1930 s, the sociologist of our country Fei Xiaotong introduces it in Chinese academic circle. He defines it, "community is a big collective formed in a certain region by social groups (family, clan) or social organization (organ, group) correlative in life, an ordered space in certain geographic area for people to live, learn, work and rest". A community includes the common geographical environment, service facilities, cultural background, life style and system as well as management organization.

Since the reform and opening-up, the economic development mode of our country has had earth-shaking changes, transforming from collective ownership to combination of collective ownership and individual ownership. Correspondingly, the traditional community mode and function also changes. Functionally, the community is a regional life unity and synchronic space for people to live. Furthermore, community is an important region for people on organization and emotion and one of the spiritual affiliations. In this way, "community means members living in certain region have stable social and psychological connection, and the community construction is to base on regional and social characteristics to promote and improve the community of human life through construction of software and hardware." At present, our country has entered the period of mass society and mass consumer culture. The function of community will change. Therefore, we must change the contradictory state faced by community masses in the new period through some ways.

\section{EXPRESSION METHODS OF COLOR DESIGN IN COMMUNITY}

Art design is an art with visual to grasp the world, reflect the society and express feelings through tools, materials and modeling means. It is important to introduce the art thinking in the construction of community culture.

"Community color design" refers to artistic activities taken in the public cultural space of community, "to develop the community and improve the members' quality and life quality". Design is not only a major medium of aesthetics but also an effective carrier of history, tradition and culture. Therefore, it achieves information transfer, cultural inheritance and educational cognition. At the meantime, design is also an art of "language", namely visual language. It has special ways of cognition, reaction, thinking and exhibition. Therefore, visual arts can construct community culture.

Color design has diversified expression methods in community including instance method, festival method and custom method. Instance method integrates and beautifies the space environment of community with fine art works and common things like mural arts, featured landscape, lantern, paper-cut and sculptures. The appearance of traditional and the novel fine art works is conducive to shaping the cultural image of community, broadening residents' horizon and strengthening their sense of belonging. The festival method is to improve the art taste of community through artistic creation of typical key festivals, conscious spreading of community brand and cultural concept. The custom method combines with the traditional Chinese festivals and arouses people's interests in traditional culture and excellent history through group recreation and visual dynamic goods.

\section{CASES OF URBAN ART COMMUNITY}

Dulux has launched the activities of coating the city since 2010 in China, including Shanghai Shikumen, Guangzhou Higher Education Mega Center in 2010, Lengshuijiang Dam, 
large underground parking garage in 2011 and coating activity of "Whole City Coating Refreshing Season" in 2012. Dulux uses unique colors to coat, adheres to the brand idea of Adding Colors to People's Lives to express, pass and carry forward the unique spirit and culture of cities and refresh living environment and emotional energy through colors. On the basis of years of accumulation and continuous sublimation of understanding that colors refresh life, Dulux launched the coating activity with theme of "Beautiful China Begins with Colors" in 2013. According to the "inspiration", "vigor" and "romance" represented by exclusive colors, Dulux chooses Shanghai of "inspiration collision", Dalian of "vigor explosion" and Xiamen of "romantic charm" as the first three stations in this activity.
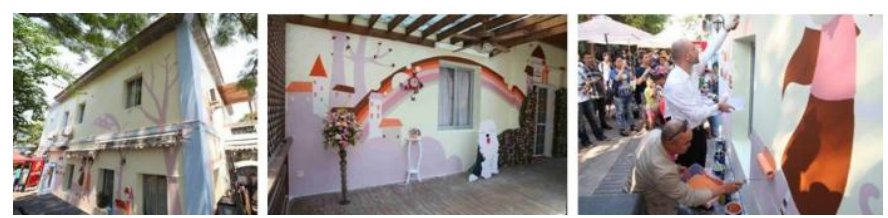

Fig. 1. Color case of Dulux in Xiamen in 2013

In 2014, Akzo Nobel launched a global plan "Human and City", emphasizing six important social issues including color, cultural history, transportation, sports, education and sustainable development, in order to vitalize the city and the community and create more humanized living environment through activities. It aims at letting urban community have more charm to change urban culture through colors, and the masses see, touch and feel the power of colors closely. Therefore, the customer group of "Dulux", the world-famous paint brand of building decoration under Akzo Nobel company transfers from the urban landmark building to urban community building. On Sept. 27 of the same year, it finished one of the cases, Shanghai Vanke Chunshen Community. The wall with off-white color for more than ten years now has colorful paintings. It lightens the way to home for residents and boosts the relationship between neighbors. The community becomes a home full of colors and warm. Meanwhile, the project of "colorful begin and refreshing community" of Dulux begins.

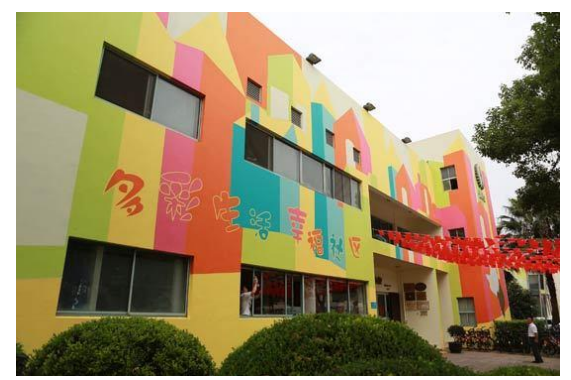

Fig. 2. External wall of Vanke service center

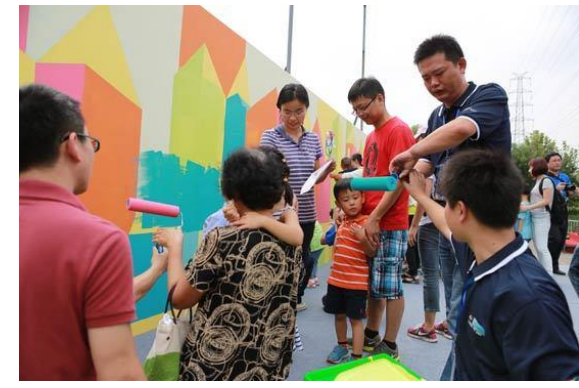

Fig. 3. Mass refreshing community

\section{The Value of Color Design in Construction of COMMUNITY CULTURE}

With the transformation of economic pattern and community, instead of simply meeting people's material requirements, the community has to meet people's aesthetic demands. Therefore, the introduction of color design is remarkable for the construction of community culture.

The forms of community culture shall be diversified. Traditional cultural activities in community are simple, including play chess, act in an opera, play cards and chat. The transmission of art education can greatly enrich the leisure way of residents in community, like painting and calligraphy exhibition, paper-cut and pottery, enabling residents to experience the application of color design and the value of art education.

Colors exist everywhere. The world we can see contains color design. People's spiritual life can be enriched through understanding colors, color design and application. The application of color design in urban community is embodied through landscape color, environment color, building color and colors on fine art works. The visualized and effective color design works convey the theme of community culture, create community culture with diversified characteristics and strengthen the socialism spiritual civilization construction of China as well as improve national civilized image.

\section{CONCLUSION}

City is a complex, developmental and dynamic social product at different times and periods. City color bears crucial information of history, culture and aesthetics in urban development. It is a part of urban planning, having received increasing attentions from people.

Community is basic unit of urban society and the basis to form harmonious socialist society. It is distinctly important to strengthen the construction of harmonious community, promote the healthy development of characteristic city and coordinate the relationship between different groups of community, in order to improve people's living standard and quality in the community.

Color is a symbol and a brilliant coat of a building. It makes the building more unique. Besides, it is a vital part of building aesthetics and city beauty. 
The color design of community may be influenced by national customs, religious faith, natural environment and regional culture. The technique of expression also varies. In different nationalities and religions, colors always have very strong cultural symbol. In landscape design of urban community, the true meaning of color landscape can be embodied through reasonably using different colors and making it comply with people's psychological association. In the design of urban community, the reasonable color and skillful modeling can make people feel beauty and form powerful visual impact.

\section{REFERENCES}

[1] Wang Hongxia. Research on Landscape Color of Urban Community, Youthful Days, 2015(6)

[2] Mao Feixing. Significance of Color Design in Community Art Education, Journal of Educational Institute of Jilin Province, 2011(11)

[3] Du Shilu. Discussion on the Value of Community Art, New Arts, 2007(3)

[4] Zhu Xiali. Initial Thinking on How to Improve Community Art Education, Practice and Exploration, 2009 (2)

[5] Zhu Yan. Walk into Community and Optimize Art Teaching Resources, Journal of Inner Mongolia University for Nationalities, 2008 (1)

[6] Ding Xiong, Zhang Fuchang. Discussion on Geographical Reasons Influencing the Design of Environmental Facility of Urban Community, Journal of Changzhou Institute of Technology, 2005 (3) 